\title{
Hospital Nursing Research Program: Partnership of Service and Academia
}

\author{
Patricia Ravert \\ Brigham Young University - Provo \\ Katreena Collette Merrill \\ Brigham Young University - Provo, katreena.merrill@byu.edu
}

Follow this and additional works at: https://scholarsarchive.byu.edu/facpub

Part of the Other Nursing Commons

\section{Original Publication Citation}

Ravert, P \& Collette-Merrill, K. (2008). Hospital nursing research program: Partnership of service and academia. Journal of Professional Nursing, 24(1), 54-58.

\section{BYU ScholarsArchive Citation}

Ravert, Patricia and Merrill, Katreena Collette, "Hospital Nursing Research Program: Partnership of Service and Academia" (2008). Faculty Publications. 5250.

https://scholarsarchive.byu.edu/facpub/5250

This Peer-Reviewed Article is brought to you for free and open access by BYU ScholarsArchive. It has been accepted for inclusion in Faculty Publications by an authorized administrator of BYU ScholarsArchive. For more information, please contact ellen_amatangelo@byu.edu. 


\title{
Hospital Nursing Research Program: Partnership of Service AND ACADEMIA
}

\author{
PATRICIA RAVERT, PHD, RN, ${ }^{*}$ AND KATREENA COLLETTE MERRILL, BS, RN†
}

\begin{abstract}
Hospitals in a nonprofit mountain west corporation conducted a gap analysis to determine readiness for Magnet Recognition. Major gaps included nursing research and availability of consultation and resources for research. Based on the findings, the development of a dynamic research program promoting nursing research and evidence-based practice within hospitals was undertaken. A nursing research council was reestablished with representatives from service and academia. A literature review and analysis of corporate/academia resources were completed. The plan called for a nursing research coordinator position and development of a research budget. Academia continues to be represented on the hospital institutional review board. A semiannual research symposium including poster presentations by nursing staff and nursing students was implemented. The plan calls for development of a research fellowship program and unit-based evidence-based specialists. With administrative support and resources and partnering with nursing academia, nonteaching hospitals can develop successful dynamic nursing research and evidence-based practice programs. (Index words: Nursing research; Evidence-based practice; Magnet Recognition; Education-service partnerships; Quality improvement) J Prof Nurs 24:54-8, 2008. (C) 2008 Elsevier Inc. All rights reserved.
\end{abstract}

$\mathrm{C}$ LOSING THE RESEARCH-practice gap has never been more important. With the major concerns of a nursing shortage and patient safety, nursing practice needs to be not only free from error but also evidence based (Institute of Medicine Report, 2004). Many academicians are finding that teaching students about nursing research and evidence-based practice is more effective when relating it to clinical practice (AugustBrady, 2005; Killeen \& Barnfather, 2005; Shorten, Wallace, \& Crookes, 2001). Unfortunately, practice at the bedside is still mostly based on tradition than evidence (Melnyk, Fineout-Overhoult, Stone, \& Ackerman, 2000; Shorten et al., 2001).

Many large hospitals affiliated with universities have multiple resources for conducting and disseminating nursing research. However, most patient care occurs in smaller hospitals without these research resources. For nursing research and evidence-based practice to

\footnotetext{
*Assistant Professor, College of Nursing, Brigham Young University, Provo, UT.

$\uparrow$ Nursing Practice and Research Coordinator, Intermountain Healthcare, Provo, UT.

Address correspondence to Dr. Ravert: Assistant Professor, College of Nursing, Brigham Young University, 135 SWKT, Provo, UT 84602. E-mail: patricia_ravert@byu.edu

8755-7223/\$ - see front matter
}

reach the bedside in a consistent and systematic fashion, partnering of service and academia is essential.

\section{Background}

The gap between research and practice has been apparent since the time of Florence Nightingale, who tried to persuade nurses and administrators to have a clean environment for ill patients. With the inception of the first formal education of nurses in the 1800s, the question of a gap between nursing research and service became evident. A 1984 landmark article discussed three models of nursing research: first, university-based research where faculty or graduate students initiate research to be implemented in the laboratory or practice setting; second, agency-based research where the agency hires a researcher to conduct research within the facility; and third and most effective, collaboration that bonds education and practice (Lancaster, 2005). The advantage of an agency-based model is that clinical nurses can be somewhat involved. In the collaboration model, educators and practitioners are equal partners who join forces at each stage of the research process and draw on each other's expertise to conduct and disseminate research.

Partnering with service and academia is mutually beneficial and has proven to be effective in launching 
nursing research initiatives (Engelke \& Marshburn, 2006; Haas et al., 2002; Weaver, Warren, \& Delany, 2005). One such partnership reported successful creation of an alliance with nine health care and academic organizations (Caramanica et al., 2002). The partnering resulted in annual research conferences, presentations by nurse authors, roundtables, and rapid dissemination of research into practice. Academic institutions have a vested interest in conducting and disseminating research. They have the fundamental knowledge and skills to conduct research and answer clinical questions. Smaller colleges that do not have strong research programs may need clinical topics for their research. Service organizations are constantly working to improve patient outcomes and implement patient safety, but many lack the skills to conduct needed research.

The Magnet Recognition Program emphasizes the importance of nursing research and even requires it in the hospital setting. However, it is unrealistic to expect all nurses to be principal investigators on research projects or to apply for funding. The American Nurses Association position statement outlines education for participation in nursing research (American Nurses Association, n.d.). The associate degree nurse's role is outlined as identifying clinical issues and helping to collect data. The baccalaureate-prepared nurse has added responsibilities related to research, such as helping investigators gain access to clinical sites for research, influencing the method of data collection, and implementing research findings. Nurses prepared at the master's degree level are educated as clinical experts and collaborate with experienced researchers in the research process including proposal development, data collection, and data analysis and interpretation. Nurses prepared at the doctoral level are educated to design research studies, collaborate with other researchers, seek research funding, and disseminate findings.

Pravikoff, Tanner, and Pierce (2005) stated that an important barrier to use of research in practice is lack of time. Other significant institutional barriers to use of research were the following: (a) presence of other goals with a higher priority, (b) difficulty in recruiting and retaining staff, (c) lack of organizational budget resources (d) organization perception of lack of nurses eager for research, and (e) organization perception that research is not achievable in the real world. The organizational budget resources for information sources such as research databases and libraries, as well as computer access and training, are often lacking.

Nursing research is a necessary component for Magnet Recognition. As many hospitals across the country seek Magnet status, it becomes necessary to explore the nursing research component and refine their program. The first hospitals in the nonprofit mountain west corporation 22-hospital system to receive the recognition were three teaching hospitals. The corporation encouraged all of their hospitals to begin the journey to Magnet Recognition.

\section{Analysis of Nursing Research Status Within Hospitals}

A Magnet task force from three hospitals in a nonprofit mountain west corporation with approximately 500 inpatient beds and 1,000 nurses conducted a gap analysis to determine readiness for the Magnet Recognition Program. A major barrier to moving toward Magnet Recognition was implementation of research and evidence-based practice. There were 13 sources of evidence in the Magnet Recognition Manual that were identified as relating to nursing research and/or evidenced-based practice (see Table 1). The gap scoring ranged from 1 (no evidence) to 5 (significant evidence to support the criteria). The results of the gap analysis revealed a range from 1 to 4 with a mean of 2.6 (see Figure 1). The major gaps included research being conducted by RNs and availability of consultation and resources for research. The most significant barriers identified were hospitals that were not affiliated with a teaching university and the educational level of the nursing staff. A survey of 696 direct care nurses found that the highest level of nursing educational preparation was as follows (approximated values): $60 \%$, associate degree; $30 \%$, bachelor's degree; and $2 \%$, master's and/or doctor of philosophy degree (see Figure 2).

In 2004, nursing research committees and hospital journal clubs were organized, but because of the programs and resources, they were not active. Corporate resources were available in the form of statisticians, grant writing, and sophisticated quality improvement programs, but these were not being utilized to their full potential. In addition, a preliminary survey of 114 nurses from one of the three hospitals revealed that although $49 \%$ felt research was important for improving practice, only $46 \%$ felt that they knew the definition of evidencebased practice.

\section{Process}

The leadership of the three hospitals commissioned a research council to be reorganized to bridge the research gaps. In March 2005, a nursing research council was formed with representatives from service and academia. A literature search, review of academic and corporate resources, and review of the work of the previous research committee were completed. Based upon the findings, an ambitious strategic plan was put in place, which included the following: development of the nursing research coordinator position, collaboration with academia, seizing opportunities, obtaining research resources, and encouraging dissemination of research findings.

\section{Nursing Research Coordinator}

It was determined that for the program to be successful, a position dedicated for nursing research and a specific budget were essential. This position needed to be a part of the nursing leadership team and report to the chief nursing officer. The goal of the position would be to coordinate the research council and its activities, identify 
Table I. Magnet Recognition Standards That Apply to Research and Evidence-Based Practice

\begin{tabular}{|c|c|}
\hline Force of Magnetism & Source of Evidence \\
\hline Quality of care & $\begin{array}{l}\text { Supply documentation of all nursing research activities that are ongoing, including internal validation } \\
\text { studies, internal and external research, and participation in surveys completed within the past } 12 \text { months. }\end{array}$ \\
\hline Quality of care & $\begin{array}{l}\text { Provide a copy of the nursing budget or other sources of funding for the past year, the current year to } \\
\text { date, and the future projection highlighting the allocation and utilization of resources for nursing research. }\end{array}$ \\
\hline Quality of care & $\begin{array}{l}\text { Provide evidence of education and mentoring activities that have effectively engaged staff nurses in } \\
\text { research and/or evidence-based practice activities. }\end{array}$ \\
\hline Quality of care & $\begin{array}{l}\text { Describe resources available to nursing staff to support participation in nursing research and nursing } \\
\text { research utilization activities. }\end{array}$ \\
\hline Quality improvement & $\begin{array}{l}\text { Provide examples of nurse involvement in evidence-based quality initiatives to improve coordination and } \\
\text { delivery of care across the continuum of services. }\end{array}$ \\
\hline $\begin{array}{l}\text { Consultation and } \\
\text { resources }\end{array}$ & $\begin{array}{l}\text { Give examples of how networking activities, professional organization participation, and use of consultants } \\
\text { and advanced practice nurses have contributed to enhancing patient outcomes. }\end{array}$ \\
\hline $\begin{array}{l}\text { Consultation and } \\
\text { resources }\end{array}$ & $\begin{array}{l}\text { Give examples of how networking activities, professional organization participation, and use of consultants } \\
\text { and advanced practice nurses have contributed to enhancing the practice of nurses at all levels in the } \\
\text { organization through enhancement of their knowledge and skills. }\end{array}$ \\
\hline $\begin{array}{l}\text { Consultation and } \\
\text { resources }\end{array}$ & $\begin{array}{l}\text { Describe the organization's relationship with educational institutions (including schools of nursing) for } \\
\text { consultation and building a collaborative/professional nursing community. }\end{array}$ \\
\hline Autonomy & $\begin{array}{l}\text { Demonstrate how direct care nurses use available professional standards, literature, and research findings } \\
\text { to support control over nursing practice, independent decision making, and assertiveness/leadership in } \\
\text { patient care management and practice. Provide evidence from multiple patient care settings within the } \\
\text { organization }\end{array}$ \\
\hline Autonomy & $\begin{array}{l}\text { Provide evidence that nurses throughout the organization have access to the Internet, library, and/or } \\
\text { other appropriate literature/data sources. }\end{array}$ \\
\hline $\begin{array}{l}\text { Community and the } \\
\text { hospital }\end{array}$ & $\begin{array}{l}\text { Describe partnerships established by the organization and/or by nurse leaders with community-based } \\
\text { entities to advance nursing practice within the organization. }\end{array}$ \\
\hline $\begin{array}{l}\text { Community and the } \\
\text { hospital }\end{array}$ & $\begin{array}{l}\text { Describe programs and outcomes that have resulted from nursing collaborations/partnerships with other } \\
\text { nursing entities in the community (e.g., nursing school, nurse researchers, consortium work, outreach } \\
\text { programs) or region. }\end{array}$ \\
\hline $\begin{array}{l}\text { Professional } \\
\text { development }\end{array}$ & $\begin{array}{l}\text { Submit a report that details how education is provided regarding ethical issues, nursing research, and } \\
\text { evidence-based practice, and include learning objectives, a content outline, and numbers of employees } \\
\text { (specifically identifying the number of nurses) who were educated in the } 12 \text { months prior to application } \\
\text { submission. }\end{array}$ \\
\hline
\end{tabular}

and support ongoing projects, and make nursing research visible within the organization. A nursing research coordinator job description was created, and a research budget within the department of nursing was developed. The nursing research coordinator reports directly to the chief nursing officer and is a member of the senior nursing leadership team.

\section{Collaboration With Academia}

A relationship existed between the hospitals and a local university with a college of nursing. Faculty members were already members of the hospital's institutional review board and were actively involved with nursing students in the hospital. Some of the faculty also worked part-time at the hospitals, and the hospital was used as a research study site for the faculty. A doctorally prepared faculty member was invited to be an active member of the nursing research council. Through partnering with the dean of the college and the chief nursing officer, university faculty members were encouraged to collaborate with the hospital as they conducted research in clinical settings. A list of expert resources for research and consultation was developed, which included faculty from the local college of nursing.

\section{Seizing Opportunities}

Several opportunities to encourage nursing research and to show the existence of nursing research had not been utilized. The research council discussed opportunities and planned the following activities to occur during the coming year: quality improvement workshop, partnering with students, and supporting employees' education efforts.

Quality Improvement Workshop. Quality improvement was a strong focus in the hospitals for some time. Each quarter, several employees attended a corporate quality improvement workshop that resulted in the completion of an improvement project and poster presentation. The posters were presented at the corporate level but not at the hospital level where the project was actually completed. Capitalizing on the current structure is a key component to creating a vital nursing research environment. Each graduate from the quality improvement workshop was invited to a workshop alumni luncheon. Posters from their projects were presented. A keynote address included the difference between quality improvement and research, moving quality improvement projects into research, and how to publish findings. 


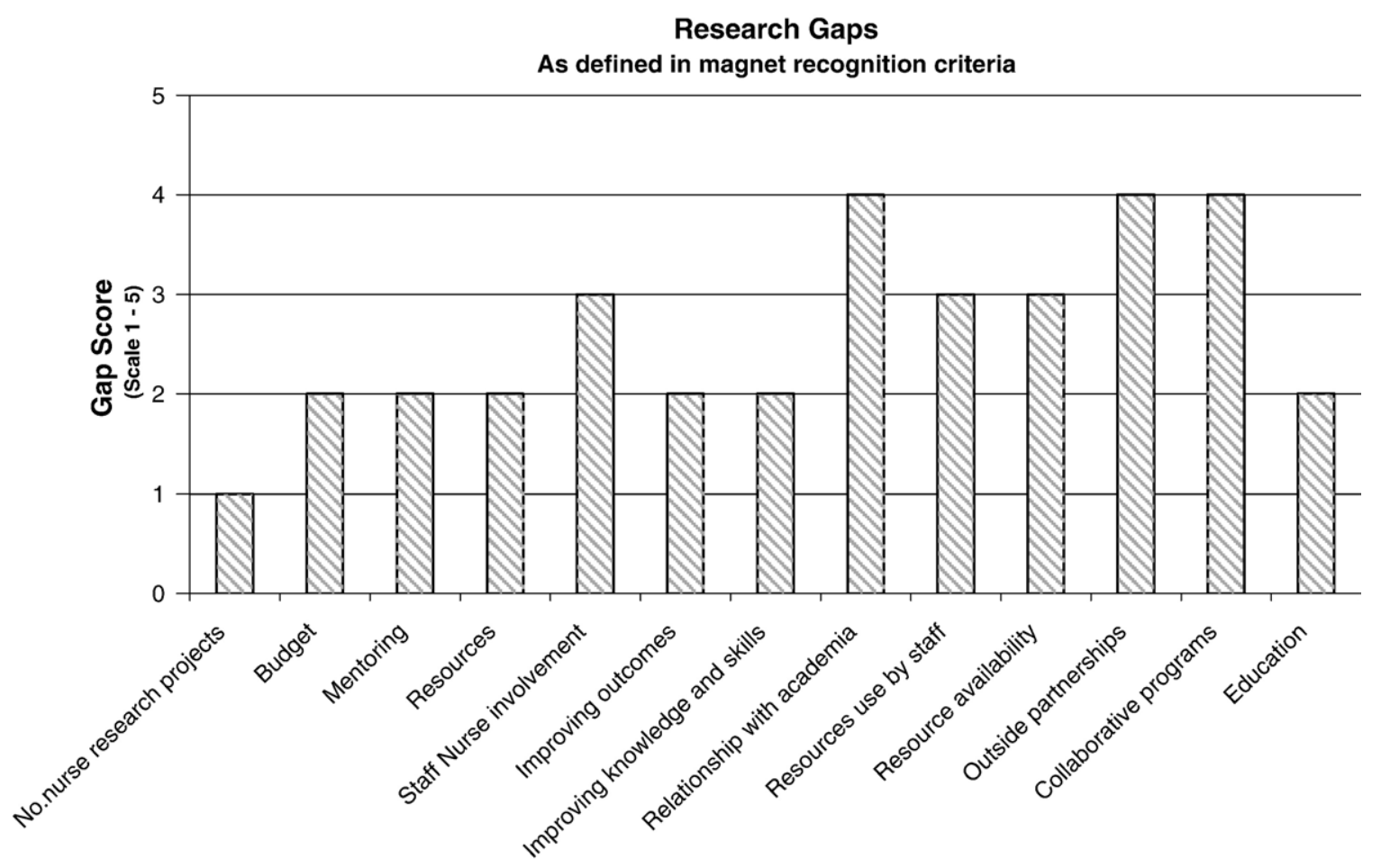

Figure I. Research and evidence-based practice gap analysis.

Partnering With Students. Through collaboration with the academia, the research council discovered that students during their final semester were required to complete a small project and display their work in a poster session at the university. Students enrolled in a research course were also required to complete a comprehensive literature review in a poster format. Capitalizing on these projects, the hospital sponsored a nursing research symposium to coincide with the university poster presentations. Students were invited to the hospital to present their posters to the nursing staff. About $70-80$ posters have been presented each session at the semiannual event.

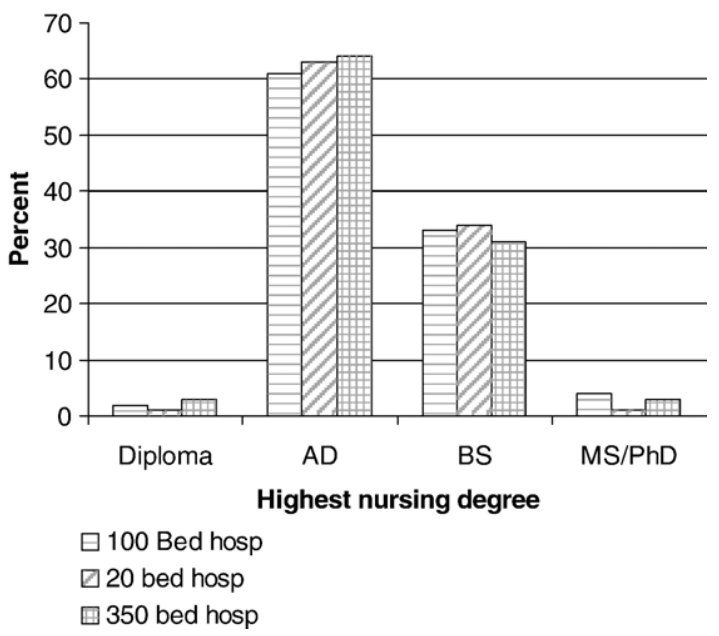

Figure 2. Level of nursing education.
Supporting Employees' Education Efforts. In 2005, a progression model was implemented, encouraging nurses to further their education for advancement in the organization. The research council identified this as an opportunity to both support these nurses and capitalize on the literature review and research projects they were involved with at a student level. The nurses who were in school both for baccalaureate and master's degrees were identified by the research council. A letter was sent to each candidate, informing them of the resources available and encouraging them to choose projects for their study that included issues identified in the hospital setting.

\section{Research Resources}

One of the barriers to research as identified by Pravikoff et al. (2005) is access to and ability to use computer resources. The organization has computers available; however, the council felt that the nursing staff was not well trained in their use. The nursing research council sponsored a library open house. One of the facilities has only 20 licensed beds and no library. The medical librarian went to the small hospital and, using a computer with a projector, showed the nurses how to access electronic resources that are available to them even at this small hospital.

\section{Encouraging Dissemination of Research Findings}

Along with developing the semiannual nursing research symposium, visibility of nursing research was needed. In the fall of 2005, several calls for abstracts were received by the nursing research coordinator. This was seen as an opportunity to encourage those who had worked on projects to submit abstracts to their specialty 
conferences. Managers and educators were approached with the challenge to submit abstracts that reflected their major accomplishments. As a result of the challenge, three abstracts were submitted and accepted, and one department expressed interest in conducting a research project.

\section{Developing Skills for Research}

It was evident that the nurses in the hospital were interested in research and evidence-based practice but lacked the necessary skills and resources. A proposal for a research fellowship program was developed. The proposal included step-by-step courses to assist nurses to develop a question and set up a project, one-on-one consultation with statisticians and faculty to design the study, and protected time to complete the study. The proposal was submitted to the hospital's charitable foundation for funding.

\section{Future Planning and Recommendations}

There are many opportunities to increase nursing research in the future. One major recommendation is a formal joint appointment between the hospital and an academic institution. This will provide the ongoing support needed to foster research in the three hospitals. At the time of publication, the nursing fellowship has yet to be funded. A less expensive alternative that has been proposed is a unit-based, evidence-based specialist. The proposal calls for nurses on each unit to be trained as evidence-based specialists and work closely with both the practice and research councils to ask questions and help develop active interest in research at the bedside. Future plans also include scheduled classes on how to write abstracts and develop poster presentations. The research council plans to partner with the practice council to foster staff presentations at the semiannual research symposium.

\section{Conclusions}

What began as a movement to gain Magnet Recognition has increased the nursing research visibility and opportunities in the clinical setting. Staff nurses are more aware of research and evidence-based practice in solving clinical issues. The staff nurses are realizing that they can be part of the research team under the leadership of nurse researchers. Through this endeavor, the relationship of researchers in academia and nonteaching hospitals has developed and will lead to improved patient outcomes. The nonteaching hospitals find added support for nursing research through partnering with academia.

\section{References}

American Nurses Association. (n.d.). Education for participation in nursing research (position statement). Retrieved July 30, 2007, from http://www.nursingworld.org/readroom/ position/research/rseducat.htm.

August-Brady, M. (2005). Educational innovations. Teaching undergraduate research from a process perspective. The Journal of Nursing Education, 44, 519-521.

Caramanica, L., Maljanian, R., McDonald, D., Taylor, S., MacRae, J., \& Beland, D. (2002). Evidence-based nursing practice, Part 1: A hospital and university collaborative. The Journal of Nursing Administration, 32, 27-30.

Engelke, M. \& Marshburn, D. (2006). Collaborative strategies to enhance research and evidence-based practice. The Journal of Nursing Administration, 36, 131-135.

Haas, B., Deardorff, K., Klotz, L., Baker, B., Coleman, J., \& DeWitt, A. (2002). Creating a collaborative partnership between academia and service. The Journal of Nursing Education, 41, 518-523.

Institute of Medicine report, keeping patients safe: Transforming the work environment of nurses. (2004). ISNA Bulletin, 30,1 .

Killeen, M. \& Barnfather, J. (2005). A successful teaching strategy for applying evidence-based practice. The Journal of Nursing Education, 30, 127-132.

Lancaster, J. (2005). Bonding of nursing practice and education through research... including commentary by Tilbury MS... originally published in September 1984. Nursing Education Perspective, 26, 294-299.

Melnyk, B., Fineout-Overholt, E., Stone, P., \& Ackerman, M. (2000). Evidence-based practice: The past, the present, and recommendations for the millennium. Pediatric Nursing, 26, 77-80.

Pravikoff, D. S., Tanner, A. B., \& Pierce, S. T. (2005). Readiness of U.S. nurses for evidence-based practice. The American Journal of Nursing, 105, 40-51.

Shorten, A., Wallace, M., \& Crookes, P. (2001). Developing information literacy: A key to evidence-based nursing. International Nursing Review, 48, 86-92.

Weaver, C. A., Warren, J. J., \& Delany, C. (2005). Bedside, generate evidence-based knowledge classroom and bench: Collaborative strategies to for nursing practice. International Journal of Medical Informatics, 74, 989-999. 